\title{
The influence of United Nations High Commission for Refugees healthcare intervention on the socioeconomic status of refugees in Gihembe camp
}

\author{
Adrienne GWIZA ${ }^{1}$ and Jaya Shukla ${ }^{2}$ \\ 1,2 Business and Economics, Mount Kenya University \\ Kigali, Rwanda
}

\begin{abstract}
The crisis of refugees has hit its highest and reached critical volumes in the contemporary world. With different governments, communities and the United Nations High Commission for refugees (UNHCR) body trying to keep side by side of offering the necessary humanitarian support to the refugees who are fleeing war and persecution, the United Nations High Commission for refugees is mandated to lead, respond and coordinate worldwide action for the international protection and resolution of refugees problems and its fundamental responsibility to safeguard the legal rights and the well-being of refugees across the world Srinivas (2009). The United Nations High Commission for refugees program is determined and focused to enable refugees to achieve self-reliance as well as have their contribution to the communities and promote combined efforts between humanitarian action and longer-term partnership-based cooperation and development. The study was aimed at assessment to access the level of influence of UNHCR healthcare intervention on the socioeconomic status of refugees in Gihembe camp. A descriptive survey design was employing Questionnaires and interviews were used to collect primary data. $87.2 \%$ of the respondents reported communicable diseases as being the commonest diseases among the refugees in the camp. UNHCR health care intervention program reduced on the infant \& maternal mortality yet $25.6 \%$.
\end{abstract}

Keywords: influence of UNHCR, healthcare intervention healthcare intervention refugees and Gihembe camp

\section{Introduction}

The research was conducted on the Gehembe Refugee Camp which was located in Byumba town, Kageyo sector in Gicumbi district in the Northern province 60 Kilometers from Kigali City. The camp was established in December 1997 with an aim of hosting Congolese refugees who had fled conflict in the Eastern Democratic Republic of Congo and initially hosted at Mudende camp which was formally located in Rubavu District. The study will be significant as it will provoke more humanitarian responses of the governments and international bodies mandated to protect the well-being of the refugees in Rwanda and beyond. This study applied a descriptive survey design and the target population was 322 people, who comprised of camp village leaders, community mobilizers and the UNHCR staff from which a sample of 76 respondents was calculated using the Slovin's formula at marginal errors estimated at $10 \%$. The researcher applied stratified sampling technique during the sample selection process. Data collection instruments were questionnaires and an interview schedule. It is in this regard that United Nations High Commission for refugees comes into picture. With its mandate to lead and coordinate international action for the global protection of the refugees as well as the resolution of refugee problems and to safeguard the refugees' legal rights plus their well-being, the UNHCR came in to provide humanitarian assistance and have acted as a savior of a countless number of people with food, shelter, education and healthcare facilities. Through its generous contributions and from other international donors and partners, Gihembe refugee camp has been transformed into a modern camp with semi-permanent structures and innovative response plans. Right from the onset of the crisis, UNHCR established temporary tents and now communal hangers for all the refugees in the camp.

\section{The Concept of UNHCR}

The UNHCR Agency was established after the World War II with the fundamental aim of helping Europeans who had been displaced by the war. Having been established in December 1950, the 
agency was given a three years mandate to accomplish its responsibilities and wind up its work (United Nations, 2009). However, in the following years, displacement grew into a worldwide phenomenon and during 1960s, the colonization of African produced the first of the continent refugee crisis and definitely, the UNHCR responded with greater humanitarian assistance.

According to the World Bank (2007), socioeconomic development is a comprehensive concept which addresses the general problems that that influence social communities as well as affect the quality of their social lives. It is mainly concerned with the measures that mobilizes domestic resources including human capital for production boast, employment stimulation, income raise, poverty reduction and overall improvement on the peoples' standards of living in the communities (World Bank 2007).

The United Nations High Commission for Refugees (UNHCR) has recently documented high levels of forced global displacement especially the end of 2016. There were approximately 65.6 million people who had been forcibly displaced as a result of the ever-increasing wars, conflicts and persecution across the world (UNHCR 2017).

The UNHCR healthcare intervention on the socialeconomic status of refugee

Due to civil disturbances from the refugees' communities in the world, various refugees from diverse countries of origin share common health challenges. Additionally, a huge number of refugees have very deprived or disrupted access to healthcare services Stauffer \& Weinberg (2009). Limited access to medical care may translate into shortage of healthcare or periodical availability. The health problems of the refugees include among others; untreated communicable disease, like tuberculosis which comes as a result of overcrowded and primitive living conditions, chronic conditions which are often exacerbated by lack of health care systems and nutritional problems which result from occurrences like famine, war, poverty and sometimes the combination on these three occurrences.

Refugees who resettled in the USA and the UK as well as in Australia have all shown signs of increased risk of suffering from malnutrition, anemia, tuberculosis, malaria, HIV and hepatitis, Stauffer \& Weinberg (2009). While several mental disability is an inadmissible conditions for people with refugee status, it remains a clear risk for all the refugees to have mental health problems for numerous reasons.
Other studies reveal that; refugees are perceived to have considerable amount of needs with a greater number of challenges which are associated with their health care. Consequently, some patients among the refugees are often denied admission into practice Burnett \& Peel (2001). Throughout the empirical literature, research findings confer that, being able to recognize refugees and particularly the most recent arrived ones, can be a very great challenge Hargreaves et al., (1999). Scarce knowledge concerning particular health problems endemic in the refugees' countries of origin or in the regions from which refugees have traveled through, are often quoted a common concern among healthcare providers Burnett \& Peel (2001).

Correspondingly, research has provided evidence that the environment has a greater influence on the health of the refugee patients, their general wellbeing and the recovery from illness. Astonishing findings from one research showed that, the whole lot of things right from the building location, to the workspace and the waiting areas can potentially affect the anxiety levels of the patient Rice et al., (2018). Another research by Douglas \& Douglas (2005) propounded that; being focused on the structure of clinic designs and healthcare care environment can be a positive influence on the health outcomes of the patient. While it may always be practical or possible to modify the clinical environment. When refugees run away from wars, conflict or persecution, and flee across their borders for sanctuary in the camps, the international bodies normally provide them with treated insecticide blankets, mosquito nets, traps, grass and mats. Nonetheless, these insecticide treated mosquito nets more often than not lose their effectiveness after some period (normally between 3-5 years) and need replacement which is often not done Lorenz (2014). The UNHCR launched a "Nothing but Nets" Campaign which aimed at delivering mosquito nets to prevent malaria in particular amongst children and pregnant women to end the disease but malaria is still very rampant among the refugees often infecting millions and millions annually.

\section{Data collection methods}

A descriptive survey design was employing Questionnaires and interviews were used to collect primary data. Using the Slovin's formula 76 respondents out of the 322 target population was selected which comprised of the camp community mobilizers were the majority who made a percentage of $81 \%$, the UNHCR staff working with Gihembe refugee camp that made up a percentage of $15 \%$ and finally the camp village leaders who made up a 
percentage of $04 \%$ who were selected according to proportional piling.

\section{Results}

UNHCR healthcare intervention on the social-economic status of refugee
In order to address research objective two of this study, questions 4,5 and 6 of section $\mathrm{C}$ in the questionnaires were asked by the researcher in order to find answers to the questions and the responses to the questions were presented in sequence of the subsequent tables in this section. Rating was done in line with the Likert scale of five rankings, thus strongly agree, and Agree, Neither agree nor disagree, Disagree and strongly disagree.

Table 1: Common health issues among refugees in Gihembe refugee camp

\begin{tabular}{|c|c|c|c|c|c|c|c|}
\hline Item Statement & SS & $\begin{array}{l}\text { Strongly } \\
\text { agree }\end{array}$ & Agree & $\begin{array}{l}\text { Neither } \\
\text { agree } \\
\text { Nor disagre }\end{array}$ & \multicolumn{3}{|c|}{$\begin{array}{l}\text { Disagree Strongly Total } \\
\text { disagree }\end{array}$} \\
\hline $\begin{array}{l}\text { Communicable } \\
\text { diseases }\end{array}$ & 76 & $37.4 \%$ & $49.8 \%$ & $5.4 \%$ & $04.3 \%$ & $03.1 \%$ & $100 \%$ \\
\hline $\begin{array}{l}\text { Non-communicable } \\
\text { diseases }\end{array}$ & 76 & $10.2 \%$ & $44.3 \%$ & $03.1 \%$ & $27.2 \%$ & $15.2 \%$ & $100 \%$ \\
\hline Mental health disorders & 76 & $04.2 \%$ & $12.4 \%$ & $14.9 \%$ & $38.3 \%$ & $30.2 \%$ & $100 \%$ \\
\hline Malnutrition & 76 & $14.3 \%$ & $22.2 \%$ & $12.5 \%$ & $36.9 \%$ & $14.1 \%$ & $100 \%$ \\
\hline Stress-related disease & 76 & $12.2 \%$ & $22.4 \%$ & $44.9 \%$ & $12.3 \%$ & $08.2 \%$ & $100 \%$ \\
\hline
\end{tabular}

Source: Primary data (2020)

As seen in Table 1 respondents were asked to give their views about the most common disease which affect refugee in Gihembe refugee camp. 87.2\% of the respondents reported communicable diseases as being the commonest diseases among the refugees in the camp but only $7.4 \%$ of the respondents were not of the same opinion and at least about $5.4 \%$ was not sure about the answer to this question. Similarly, $54.5 \%$ of the respondents reported non communicable diseases yet $42.4 \%$ did not agree with this statement and only $3.1 \%$ neither agreed nor disagreed with the statement.

When respondents were asked about the malnutrition issues in the camp, $36.5 \%$ strongly agreed with this statement yet $51 \%$ did not approve of this statement and at least only $12.5 \%$ of the respondents remained neutral to this statement. One the other hand, $34.6 \%$ of the respondents reported that; stress-related diseases had a significant effect on the lives of most refugees in Gihembe camp yet $20.5 \%$ were in disagreement with this statement yet the majority $44.9 \%$ had no idea about this question. Respondents were also asked about the mental health issues in the camp and only a few $16.6 \%$ were in agreement with this statement yet the majority did not agree and only $14.9 \%$ were undecided. This implied that, outbreaks of communicable diseases are a constant threat to the lives of the refugees who thought they would be safe in the camps as a result of overcrowdings often causing viral infections transmitted through contaminated food and water or even through poor housing conditions. The research findings of Burnett \& Peel (2001), found out that; limited knowledge concerning particular health issues endemic in the refugees' countries of origin or in the regions from which refugees have traveled through, are often cited as a predominant concern among health care providers. 
Table 2: Health care services provided by UNHCR program to the refugee of Gihembe camp

\begin{tabular}{|c|c|c|c|c|c|c|c|}
\hline $\begin{array}{l}\text { Item } \\
\text { Statement }\end{array}$ & SS & $\begin{array}{l}\text { Strongly } \\
\text { agree }\end{array}$ & Agree & $\begin{array}{l}\text { Neither } \\
\text { agree } \\
\text { Nor disagree }\end{array}$ & Disagree & $\begin{array}{l}\text { Strongly } \\
\text { disagree }\end{array}$ & Total \\
\hline Vaccination & 76 & $29.4 \%$ & $49.8 \%$ & $06.1 \%$ & $10.6 \%$ & $04.1 \%$ & $100 \%$ \\
\hline Medical treatment & 76 & $39.5 \%$ & $57.4 \%$ & $03.1 \%$ & $00.0 \%$ & $00.0 \%$ & $100 \%$ \\
\hline Nutrition Education & 76 & $12.2 \%$ & $22.4 \%$ & $44.9 \%$ & $11.3 \%$ & $09.2 \%$ & $100 \%$ \\
\hline Clinical counseling & 76 & $12.3 \%$ & $14.2 \%$ & $22.5 \%$ & $36.9 \%$ & $14.1 \%$ & $100 \%$ \\
\hline Maternal health services & 76 & $12.2 \%$ & $36.4 \%$ & $30.9 \%$ & $12.3 \%$ & $08.2 \%$ & $100 \%$ \\
\hline $\begin{array}{l}\text { HIV testing and } \\
\text { treatment }\end{array}$ & 76 & $29.5 \%$ & $37.4 \%$ & $13.1 \%$ & $10.0 \%$ & $10.0 \%$ & $100 \%$ \\
\hline $\begin{array}{l}\text { Family planning } \\
\text { services }\end{array}$ & 76 & $19.5 \%$ & $27.4 \%$ & $33.1 \%$ & $12.0 \%$ & $08.0 \%$ & $100 \%$ \\
\hline $\begin{array}{l}\text { Pesticide treated } \\
\text { mosquito nets }\end{array}$ & 76 & $10.5 \%$ & $40.4 \%$ & $32.1 \%$ & $11.0 \%$ & $06.0 \%$ & $100 \%$ \\
\hline
\end{tabular}

Source: Primary data (2020)

As displayed in Table 2, respondents were asked to give their views on the types of health care services that are provided to the refugees by UNHCR program. Accordingly, the utmost number of respondents $96.9 \%$ unanimously reported that; medical treatment was the foremost kind of health care service that was provided by the UNHCR program to the refugees in the camp. Only $3.1 \%$ of the respondents were not sure about this prospect. On the other hand, $79.2 \%$ of the respondents unanimously agreed that vaccination was yet another type of health care service that was provided to the refugees by the UNHCR program. However $14.7 \%$ did not agree with this idea and yet only $6.1 \%$ of the respondents neither agreed nor disagreed with this statement.

Similarly, $66.9 \%$ of the respondents strongly agreed that, HIV testing and treatment was yet another type of health care service that was occasionally provided to the refugees by the UNHCR program. Only $20 \%$ of the respondents strongly opposed this statement and yet $13.1 \%$ were not sure about this statement. When respondents were asked about the idea of provision of pesticide treated mosquito nets by the UNHCR program, $50.9 \%$ of them agreed with the statement yet $17 \%$ were totally opposed to this idea but $32.1 \%$ did not provide any answer to this statement. When respondents were asked about maternal health care services, $48.6 \%$ of the respondents agreed with this item statement while $20.5 \%$ totally disagreed with idea yet $30.9 \%$ were undecided. Furthermore, $46.9 \%$ of the respondent reported family planning as one on the healthcare services provided by the UNHCR program yet $20 \%$ of them disagreed with this statement and $33.1 \%$ remained neutral regarding this statement.

In addition, there was a relatively another lesser number of respondents $34.6 \%$ who reported that; nutrition education was part of the package of health care services that were offered to the refugee yet this was refuted by a significant number of respondents $20.5 \%$ who totally disagreed with the statement but the majority of the respondents $44.9 \%$ did not have any idea about this prospect. Finally only $26.5 \%$ of the respondents propounded that clinical counseling 
was among the health care services provided by the UNHCR program yet a significant number of respondent $51 \%$ disproved this statement but $22.5 \%$ of the respondents neither agreed nor disagreed with this statement. This corresponds with the findings of
Douglas \& Douglas (2005), who propounded that; being focused on the structure health care environment and clinic designs can have a positive impact on the health outcomes of the refugee patients.

Table 3: Impact of UNHCR health care intervention program on the health of refugees in Gihembe refugee camp

\begin{tabular}{|c|c|c|c|c|c|c|c|}
\hline Item Statement & SS & $\begin{array}{l}\text { Strongly } \\
\text { agree }\end{array}$ & Agree & $\begin{array}{l}\text { Neither } \\
\text { agree } \\
\text { Nor disagree }\end{array}$ & Disagre & $\begin{array}{l}\text { Strongly } \\
\text { disagree }\end{array}$ & Total \\
\hline $\begin{array}{l}\text { Reduced child \& } \\
\text { maternal mortality }\end{array}$ & 76 & $23.2 \%$ & $30.1 \%$ & $21.1 \%$ & $15.5 \%$ & $10.1 \%$ & $100 \%$ \\
\hline $\begin{array}{l}\text { Improved knowledge } \\
\text { on nutrition }\end{array}$ & 76 & $18.2 \%$ & $37.3 \%$ & $12.1 \%$ & $15.0 \%$ & $20.1 \%$ & $100 \%$ \\
\hline $\begin{array}{l}\text { Reduced stress \& } \\
\text { depression levels }\end{array}$ & 76 & $11.2 \%$ & $41.4 \%$ & $14.9 \%$ & $23.3 \%$ & $09.2 \%$ & $100 \%$ \\
\hline $\begin{array}{l}\text { Improved knowledge on } \\
\text { HIV prevention \& treatment }\end{array}$ & 76 & $17.3 \%$ & $38.9 \%$ & $12.2 \%$ & $20.8 \%$ & $10.8 \%$ & $100 \%$ \\
\hline $\begin{array}{l}\text { Improved general physical } \\
\text { conditions }\end{array}$ & 76 & $30.2 \%$ & $41.1 \%$ & $11.2 \%$ & $09.3 \%$ & $08.2 \%$ & $100 \%$ \\
\hline
\end{tabular}

Source: Primary data (2020)

As displayed in Table 3 respondents gave their view about the impact of UNHCR health intervention program on the health of the refugees in the Gihembe camp. To that effect, majority of the respondents $71.3 \%$ of the respondents agreed that, health care services which are provided by the United Nations High Commission for Refugees Settlement Program really have improved general physical conditions of the refugees but $17.5 \%$ opposed this statement yet $11.2 \%$ neither agreed nor disagreed with the statement. The second highest number of respondents $56.2 \%$ strongly stated that; the UNHCR health care intervention program significantly improved knowledge and understanding of HIV prevention \& treatment. However, $41.6 \%$ of the respondents were totally opposed this report yet $12.2 \%$ neither agreed nor disagreed with the statement.

A significant number of respondents $55.5 \%$ strongly agreed that; the UNHCR health care intervention program improved knowledge on nutrition and proper diet yet $35.1 \%$ did not agree with the statement and only $12.1 \%$ were neutral about this statement. Correspondingly, $53.3 \%$ of the respondents stated that, UNHCR health care intervention program reduced on the infant \& maternal mortality yet $25.6 \%$ of the respondents disagreed with this statement yet $21.1 \%$ did not provide any answer to this question. In the same way, respondents who reported stress reduction were $52.6 \%$ yet $32.5 \%$ were in total disagreements with this opinion and only $14.9 \%$ were undecided.

These results indicate that the health care services of the United Nations High Commission for Refugees Settlement Program had a significant correlation with the improved health of the refugees which was reflected through high level of responses in the agree section ranging from reduced child \& maternal mortality $=53.3 \%$, improved knowledge on nutrition $=55.5 \%$, reduced stress \& depression levels $=52.6 \%$, improved knowledge on HIV prevention 
and treatment $=56.2 \%$ as well as improved general physical conditions of the refugees which had the highest number of respondents in the agree section with the percentage of $71.3 \%$. This answers research question two of this study that indeed; the United Nations High Commission for Refugees Settlement Program greatly improved the health of the refugees in Gihembe refugee camp since all the question showed a positive correlation with the highest number of respondents $71.3 \%$ unanimously agreeing that the health care intervention really Improved the general physical conditions of the refugees.

\section{Acknowledgement}

I wish to acknowledge Dr. Alice Kituyi for her contribution to this work from the beginning up to it's the completion. I also wish to extend my acknowledgement to the Mount Kenya University, Gihembe refugee camp authorities for their support and collaborative in terms of data collection.

\section{References}

[1] Burnett \& Peel (2001), towards solutions for towards solutions for protracted refugee situations: protracted refugee situations: The role of resettlement.

[2] Douglas \& Douglas (2005) Patient-centered improvements in health-care built environments: perspectives and design indicators. Health Expectations, 8(3), p. 264-276.

[3] Hargreaves, Holmes \& Frieland (2009). Health care provisions for asylum seekers and refugees in the UK. Lancet, 353

[4] Lorenz (2014), 'Migrant remittances in the context of crisis in Somali society', Humanitarian Policy Group, HPG Background Paper 25, ODI, United Kingdom

[5] Rice, Ingram \& Mizan, (2018). Enhancing a primary care environment: a case study of effects on patients and staff in a single general practice. British Journal of General Practice, 58(552), e1e8.

[6] Srinivas. (2009), Against NGOs, Critical Perspective on Non-Governmental Action, Nonprofit and Voluntary Sector Quarterly, 9(10),

[7] United Nations. (2009), World Survey in the Role of Woman in Development: Women's Control over Economic Resources and Access to Financial Resources including Micro-Finance

[8] UN Publication ISBN 978-927-130275-2

[9] UNHCR (2017), Promoting Livelihoods and Self-reliance Operational Guidance on Refugee Protection and Solutions in Urban Areas, http://www.unhcr.org/4eeb19f49.html

[10] World Bank (2007), Rural Development: A policy Analysis (Washington D. C: World Bank Press 